\title{
STRATEGIC 'MORPHING’ AND THE SURVIVABILITY OF E-COMMERCE FIRMS
}

\author{
Robert J. Kauffman \\ Professor and Department Chair \\ Bin Wang \\ Doctoral Program \\ Information and Decision Sciences \\ Carlson School of Management \\ University of Minnesota, Minneapolis, MN 55455 \\ \{rkauffman; bwang\}@csom.umn.edu
}

\section{Tim Miller}

Webmergers.com

San Francisco, CA

tmiller@webmergers.com

Last revised: August 20, 2001

\begin{abstract}
Over the past year, the shakeout in the electronic commerce marketplace has redirected the attention of entrepreneurs and investors from the funding hype surrounding Internet startups to the traditional bottom line of business: firm profitability. To improve profits and achieve strategic sustainability in a rapidly changing competitive environment, many DotComs have been repackaging themselves by targeting new markets, expanding into the offline world, forming alliances, licensing software, and adjusting their core offerings to focus on the most profitable products and customers (Chircu and Kauffman, 2000). This research develops an evolutionary game theory-motivated framework (Ba et al., 2000; Smith, 1992; Weibull, 1997) that helps academic researchers and industry practitioners to understand the "strategic morphing" of DotComs (Miller, 2001). Our framework applies an analogy from the theory of bio-diversity and genetic survivability in population ecology to different species in a highly competitive organic biome. In the e-commerce context, however, we emphasize survivability in terms of a set of characteristic categories and constructs that provide explanatory power for firm "strategic fitness" in competition with other firms and in the marketplace in general. We illustrate our framework using mini-case studies on DotCom success and failure.
\end{abstract}

KEYWORDS: Business models, digital economy, DotComs, economic analysis, e-commerce, evolutionary game theory, firm performance, market competition.

ACKNOWLEDGEMENTS: We thank Sulin Ba for helpful input on the theoretical orientation that we have used in this research, and for funding and assistance from the MIS Research Center at the Carlson School of Management of University of Minnesota. We also thank Penghui Xia for assistance with the development of some of the mini-case background. Any inaccuracies and errors are the responsibility of the authors. 


\section{INTRODUCTION}

Compared to the physical marketplace, the Internet channel enabled new DotCom firms to leverage lower startup and operational costs (Westland and Clark, 1999), easier and lower cost one-to-one marketing and customization (Bakos, 2001), as they entered the market. In addition, the Internet itself afforded many new opportunities to try out innovative business models, such as the "name-your-own-price" market offered by Priceline.com (www.priceline.com). It also offered opportunities to take existing business models into a new electronic context, such as we saw with the emergence of the online "flea market" auction market, eBay (www.ebay.com) (Kauffman and Wang, 2001). Stimulated by these advantages, venture capital firms sought out opportunities to invest historically large sums of capital, causing the number of DotCom firms to proliferate during late 1990's. Venture Economics, a division of Thomson Financial and a venture capital investment information provider, estimates that Internet-related firms in the U.S. received some US $\$ 41.8$ billion in venture capital investments in 1999 , accounting for $70.6 \%$ of the total venture capital investments that year. In 2000, the figures further increased to US\$79.1 billion and 76.0\%, respectively (Venture Economics, 2000).

Meanwhile, the market value of the DotCom firms - rationally or otherwise - also skyrocketed. Priceline.com, for example, was once valued more than the combined worth of the two largest airlines (American and United), and Amazon.com (www.amazon. com) dwarfed Target Corporation (Oliver, 2000). However, the world of the DotComs took a sharp turn in Spring 2000 back towards reality. After the stock market crash in March 2000, many Internet firms, both in the business-to-consumer (B2C) and business-tobusiness (B2B) sectors, folded as they ran out of funding before they could even reach profitability. According to Webmergers.com (2001), an Internet firm that monitors the shutdown, mergers and acquisitions in the electronic marketplace, about 600 DotComs have ceased operations since January 2000.

As the shakeout in the electronic commerce marketplace continues, entrepreneurs and investors have redirected their attention from the funding hype surrounding Internet startups to the traditional bottom line of business: firm profitability. To improve profits and achieve strategic sustainability in a rapidly changing competitive environment, many DotComs have been repackaging themselves by targeting new markets, expanding into the offline world, forming alliances, licensing software, and adjusting their core offerings to focus on the most profitable products and customers (Chircu and Kauffman, 2000). Tim Miller, President of Webmergers.com (www.webmergers.com), characterizes this phenomenon as "strategic morphing," which depicts the changes in organizational tactics and strategies, as DotComs evolve to improve their sustainability in the highly competitive marketplace (Miller, 2001).

With the recent economic downturn and the tough market environment facing entrepreneurs and investors alike, it is important to examine the success and failure of Internet firms at a more disaggregated level. The 
current research is a step in that direction. It applies a theoretical perspective from evolutionary game theory and develops a framework that identifies a set of characteristic categories and constructs that can help academic researchers and industry practitioners to understand a DotCom firm's "strategic fitness" in competition with other firms and in the marketplace in general. We try to answer the following research questions:

- How can evolutionary game theory inform us in our understanding of the path to success or failure that many DotComs have experienced?

- Can we identify a set of crucial factors or categories of factors that relate to DotCom success or failure?

口 Can we validate our findings in the real world?

We test our conceptual framework using mini-cases.

Results from the current research contribute to both theory and practice. First, this research extends our knowledge about the factors that lead to success and failure on the Internet, as well as the impact of maintaining strategic fitness in the marketplace. Second, this research is also the first attempt to apply evolutionary game theory in the setting of DotCom success and failure. Third, using the set of factors identified in the current research as benchmarks for building successful business plans, DotCom firms can proactively take strategic moves to improve their fitness with the environment and increase their likelihood of maintaining business viability.

\section{LITERATURE REVIEW}

We cite three streams of research in developing our framework of DotCom success and failure. First, we review previous research on business success and failure, from which we identify both industry- and firmrelated factors. Second, we examine recent IS research on the inherent differences among different business models and the resulting different sustainability in the online channel. Finally, we introduce evolutionary game theory, and apply it to analyze DotCom success and failure.

\section{Business Success and Failure}

Using econometric models to predict the timing of business failure in the vein of survival analysis from biomedical statistics, Audretsch and Mahmood (1991, 1995) demonstrate that both industry-specific factors and firm-specific factors can influence the propensity of a firm to fail. They characterize the hazard rate, the conditional likelihood of failure (Kalbfleisch and Prentice, 1980) of a firm (Audretsch, 1991, 1995). They include industry-related factors such as technological conditions and market demand as drivers of firm performance. Their results suggest newly-established firms, ceteris paribus, are more likely to survive in an industry that has an entrepreneurial regime (such as Internet-based booksellers) because of the innovation advantage they possess over market incumbents. An industry that has a routinized technological regime (such as computer chip makers) would favor the latter. High industry growth can also boost new entrant 
survivability since the resulting higher price-cost margins allow new startups to operate at a suboptimal scale size. Firm-specific factors include startup size and ownership structure. Firms with a larger startup size are more likely to succeed. Audretsch and Mahmood (1995) also find independent new businesses are more likely to fail than newly-established divisions of existing firms. They attribute the difference to the knowledge that existing firms possess and subsequently are able transfer to the newly- established divisions.

Hensler, Rutherford and Springer (1997) apply survival analysis in the stock market to predict the time that initial public offerings (IPOs) of stocks are delisted. Using IPO data from 1975 to 1984, they find that firm size, the age of the firm at the time of offering, the initial return of investment in the stock issue, the number of IPOs co-occuring in the market, and the percentage of the firm owned by insiders are positively related to the likelihood of survival. In contrast, a higher general price level in the stock market at the time of IPO and a larger number of firm-related risk factors can result in a higher hazard rate. The authors also show that firms that do IPOs in the optical and pharmaceutical industries have longer survival times than those in the computer and data, wholesale, restaurant and airline industries.

Honjo (2000) applies similar methods using data from the Japanese manufacturing industry from 1986 to 1994. One analysis compares the hazard rate of firms at the same firm age, and a second at the same calendar time. Honjo's results are consistent across the two methods. Financial capital and firm size appear to have some explanatory power. He argues that the significant effects of firm size from previous research might actually reflect the impact of financial capital. Moreover, Honjo asserts that higher hazard rates characterize industries that have higher entry rates and denser geographical concentrations. In the firm age-based analysis, the author finds that new startups established just before or after a market crash also appear to have higher hazard rates.

\section{EC Business Models}

Two recent research streams in the Information Systems (IS) field are relevant in our assessment of DotCom success and failure. The first stream comes from the research on network externalities. The second stream of research addresses the question "Are all business models equally likely to survive on the Internet?" Let's consider the first stream now.

Network externalities occur when the benefit of using one technology increases as the network of adopters expands (Katz and Shapiro, 1986, 1994). As a result, potential adopters are more likely to adopt a technology when there is a large network of users. Economides (1996) distinguishes two types of networks in the real world. In two-way networks, we can identify a direction of flow and network externalities come from the enlarged communication base as the number of users increases. Telephone and email are examples of two-way networks. In one-way networks, consumers only have demand for composite goods, which consist of different nodes. Network externalities in one-way networks are indirect. A paging network is an example of one-way 
network.

Researchers operationalize network size as the current installed base or expected installed base in the empirical testing of the significance and magnitude of network externalities (Dybvig and Spatt, 1983). In our assessment of DotCom survival and failure, network externalities, reflected in achieving a critical mass, present firms with a large customer base and opportunities of future growth. The first-mover advantage that Amazon.com, eBay and HotMail (www.hotmail.com) still enjoy illustrates that being the first to achieve the critical mass in a sector can put firms in the leading position relative to their competitors.

According to Mahadevan (2000), a business model consists of three interrelated parts: the value stream, the revenue stream, and the logistical stream.

ـ The value stream refers to a firm's value propositions to its customers and suppliers, such as reduced product and customer search costs and transaction costs.

- The revenue stream reflects the source of income for the business, such as advertising revenue at portal sites and increased profit margins that are available through reduced operational costs.

- The logistical stream emphasizes the logistics aspect of the firm and how the firm designs its supply chain. To this list, in view of the nature of startup and entrepreneurial nature of DotCom firms, we also would add the financial capital stream. Previous research on business success and failure reveals the amount of financial capital a firm possesses is a significant predictor of business survival. The financial capital aspect emphasizes the extent that the firm's business is able to take advantage of continuous replenishment or expansion of capital, so that its business may grow and flourish. We view this as parallel in importance to the value, revenue and logistical streams of a business model. As a result, we make it an integrated part of the overall business model. Later in our mini-case studies, we will illustrate how DotComs use different strategies to change the value, revenue, logistical and financial streams to make their business models more adaptable.

Among the four, the value and financial capital stream are levers for long-term firm advantage. Moreover, the value stream is key to the generation of revenue. As a result, for businesses to remain viable online or offline, they have to provide value-added products or services to their customers and suppliers.

However, are different DotComs equally likely to deliver value to buyers and sellers in the digital marketplace? Downes and Mui (1998) point out that firms that can provide "killer applications" are more likely to succeed. Firms that can create new value or recreate old value will also have a higher chance of survival (Mougayar, 1998). Also, businesses that structure core offerings around emerging technological standards are in a more advantageous position than those that do not (Burnham, 1999). Unique value, in the form of value propositions that the market simply has not seen before, apparently has been crucial to DotCom success.

The recent failure of many group-buying firms (Cook, 2001; Sandoval and Kawamoto, 2001) is a good 
illustration of the consequence of failing to deliver unique value to customers. The limited transaction volumes at group-buying sites prevented firms from realizing the benefits associated with the low price value proposition that these firms tried to offer to their customers (Kauffman and Wang, 2001). This fatal flaw, together with factors such as low barriers to entry and fierce competition from other online and offline retailers, soon made many group-buying firms fail.

\section{Distilling the Relevant DotCom Survival Factors}

Based on the literature on business success and failure, and the recent literature on network externalities and EC business models, we identify three sets of drivers for DotCom survival: industry-specific characteristics, firm-specific factors, and EC-specific factors.

Industry-specific characteristics include the rate of new firm entry, industry growth, and the technological regime of the industry. Firm-specific factors include financial capital a firm possesses, firm size, the founding time, percentage of insider ownership, and whether the company is an independent new startup or a new branch of an existing company. EC-related factors include whether the company has achieved critical mass and the adaptability of its business model to the marketplace.

In the next section, we use a branch of economic called evolutionary game theory to further examine these categories of variables and identify a set of factors that characterize the "strategic fitness" of the firm in competition with other companies and in the marketplace.

\section{Evolutionary Game Theory}

Evolutionary game theory is concerned with the emerging dynamics and equilibria that result in the presence of competition among individuals in a population (Smith, 1982). There are six fundamental constructs in evolutionary game theory. They are genes, mutation, the environment, competition, time and the outcome. Genes determine the characteristics of an organism, the strategies it plays in the game, and its ultimate survival in repeated games. All organisms compete with each other for the limited resources in the environment in which they reside. In this competition, all organisms start with the same gene composition. Over time, some random stimuli either from the environment or within the organism result in changes in the genes, in a process called mutation. As a result, the gene compositions among the organisms are no longer the same, and those with superior genes are in an advantageous position relative to their competitors.

The strategies they adopt make them more adaptable to the environment and give them a higher chance to reproduce. Through a series of games, the outcome is the survival of the fittest where organisms with superior genes sustain themselves and those with inferior genes are selected out of the game. This evolutionary cycle continues as new mutation occurs among the surviving organisms. (See Figure 1.)

The distinction between evolutionary game theory and traditional game theory in economics is how individuals come to realize which strategies to adopt. Unlike game theory, which assumes rational and fully 
informed players, evolutionary game theory assumes that individuals are not always rational. Instead, they may select their strategies on a trial-and-error basis, a sort of learn-by-doing approach (Samuelson, 1998). Over a series of repeated game plays that occur across time, individuals in the population are able to identify strategies that generate higher payoffs or better outcomes, and eliminate those that are less effective. By picking a particular strategy, an individual actually changes one of its "genes" for the game, making it better or worse off in competition with other individuals, as the whole population evolves.

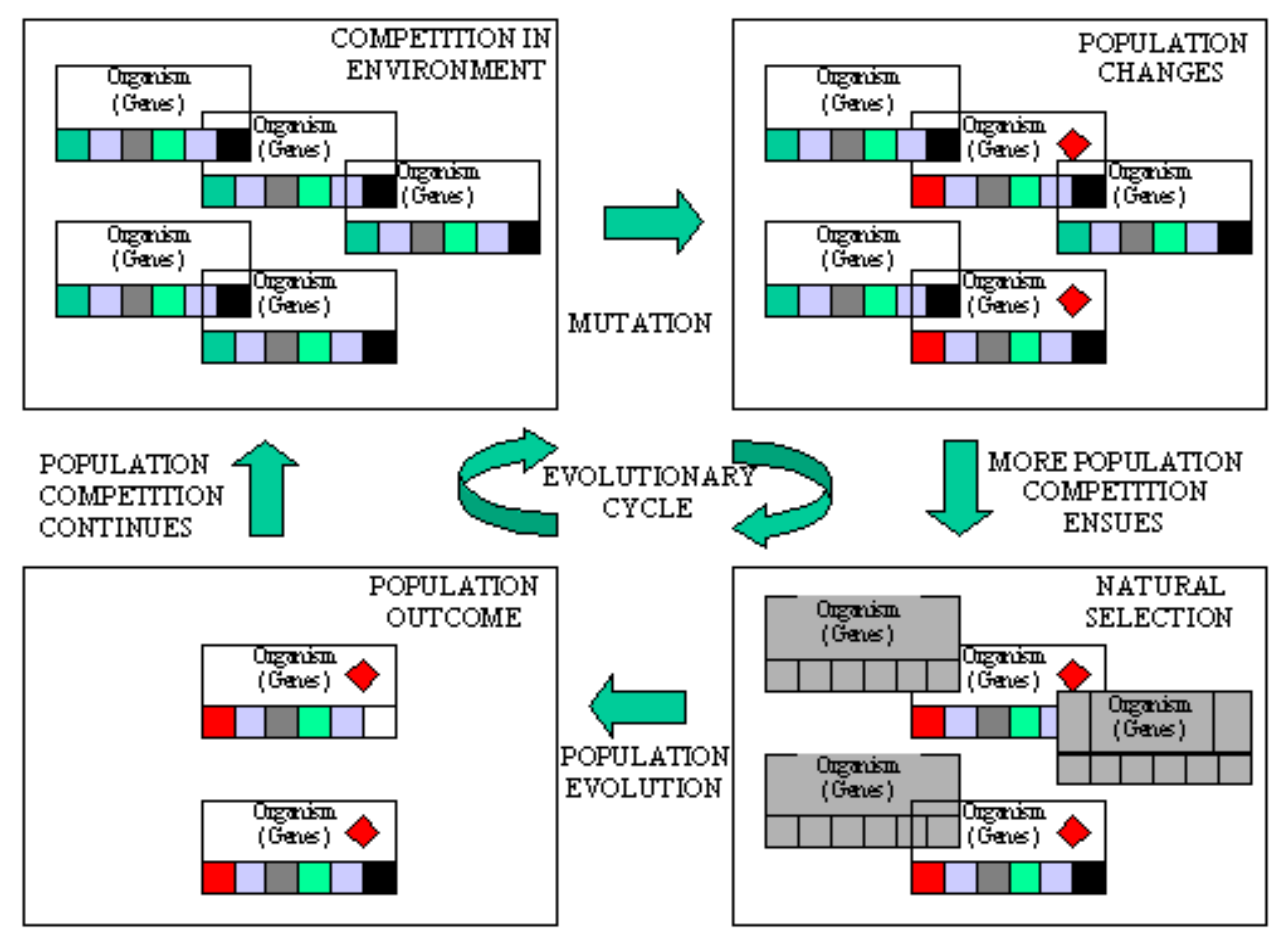

WELL-ADAFTED INDIVIDUALS SURVIVE

POORL Y-ADAFTED INDIVIDUALS WEAKEN

Figure 1. An Illustration of Evolutionary Game Theory

An important concept in evolutionary game theory is an evolutionary stable strategy (ESS), which is defined as a Nash equilibrium that is stable in the population. That is, after an ESS is established in the population, it should be able to endure the pressures of change and selection (Samuelson, 1998). This way, when a small number of individuals adopt some other mutant strategy, they are in a relatively disadvantageous position compared to those that adopt the ESS. The selection process will weed out the mutant strategy by eliminating the individuals that adopt it or by forcing them to change their strategies.

\section{AN EVOLUTIONARY GAME THEORY-MOTIVATED FRAMEWORK FOR DOTCOM STRATEGIC MORPHING}

In this section, we apply evolutionary game theory to the strategic morphing, and the success and failure of 
DotComs'. We argue that by making strategic moves, DotComs change their genes in the competition with other firms. Those that adopt better strategies are likely to withstand selection pressure in the marketplace. Let us consider how we view DotCom strategic morphing through the lens of evolutionary game theory.

\section{Theoretical Orientation and Preliminaries}

Analogous to the evolution of organisms, the survival of firms is also an evolutionary process. Firms compete for limited resources in a marketplace, such as customers, suppliers, physical materials, and financial capital. In addition, firms have different capabilities, resources, and strategies, as organisms have different genes. Among these different capabilities, resources and strategies, some will confer the firm competitive advantages, allowing a firm to outperform its rivals. Others may put the firm in a disadvantageous position. Evolutionary game theory informs us that firms come to realize which strategies pay off and which do not through a process of trial and error.

Viewed this way, the strategies that firms adopt over time to generate higher payoffs are akin to what we see in population ecology, as individuals in an organic population change their gene compositions over time with a random component. This is a learning process wherein firms come to realize what works better and what does not by experimenting, examining market feedback and financial performance, and learning from others' experience. For example, due to a firm's keen business knowledge (or possibly some random and less purposeful factors), it adopts a certain strategy. Later the firm may find out that this strategy gives it competitive advantage over its competitors and, thus, yields a higher payoff. But because of the limited scope of the market available to all competitors, the higher payoff obtained by the firm may also cause its competitors to receive lower payoffs. When other firms do not take any actions to correct this situation over time, then the stronger competitor will eventually drive them out of the market. On the other hand, if the other firms try to imitate the stronger competitor and follow the same strategy, then the basis for competitive advantage will disappear. In either case, the superior strategy prevails. Over a period of time, competition in the marketplace eliminates those that are resistant to change and those that adopt inferior strategies. This, then, generally results in the success and failure we observe in the DotCom marketplace. (See Figure 2.)

The logic of our framework bears similarities to a strategy model proposed by GartnerG2, a research division of Garther Group (Rountree, 2001b). In their model, a firm first scans and senses the external and internal environments from which it learns and acquires knowledge. This further allows the firm to innovate and adapt, resulting in the accumulation of new knowledge. This continuously expanded knowledge base enables the firm to mutate and change strategy. Gartner Group emphasizes the process of mutation as a result of the learning process firms go through to achieve higher performance outcomes.

\section{Reconsidering the Success Factors}

Evolutionary game theory informs us that "genes" that generate higher payoffs are critical to DotCom 


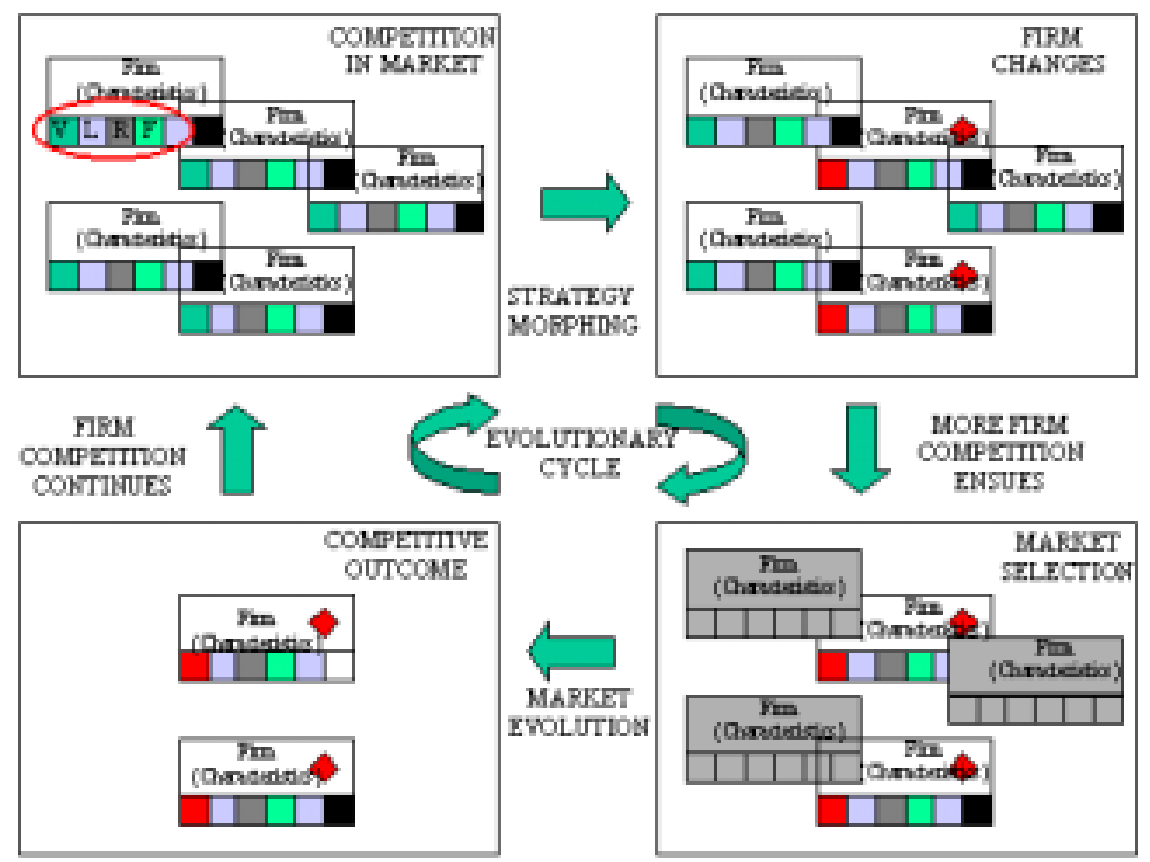

WHLLADAFTED FTOSS SURVTY

POORL Y-ADAPTED TEMS WEEKEN

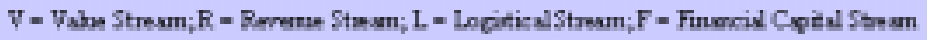

Figure 2. An Evolutionary Game Theory-Motivated Framework of DotCom Strategic Morphing

survival. Then what "genes" are superior, and which strategies will yield higher payoffs for firms? We next reconsider the factors we identified earlier that appear to be crucial to DotCom success, and discuss strategies that firms can adopt as they "morph" to improve their chance of survival. (See Table 1.)

\begin{tabular}{|c|c|c|}
\hline CATEGORY & FACTORS & STRATEGIES \\
\hline $\begin{array}{l}\text { Firm- } \\
\text { specific }\end{array}$ & $\begin{array}{l}\text { Firm size } \\
\square \text { Insider } \\
\text { ownership } \\
\text { New startup }\end{array}$ & $\begin{array}{ll}\square & \text { Market expansion } \\
\square & \text { Mergers and acquisition } \\
\square & \text { Alliances with existing firms }\end{array}$ \\
\hline $\begin{array}{l}\text { E-commerce- } \\
\text { specific }\end{array}$ & $\begin{array}{l}\text { Critical mass } \\
\square \text { Business } \\
\text { model }\end{array}$ & 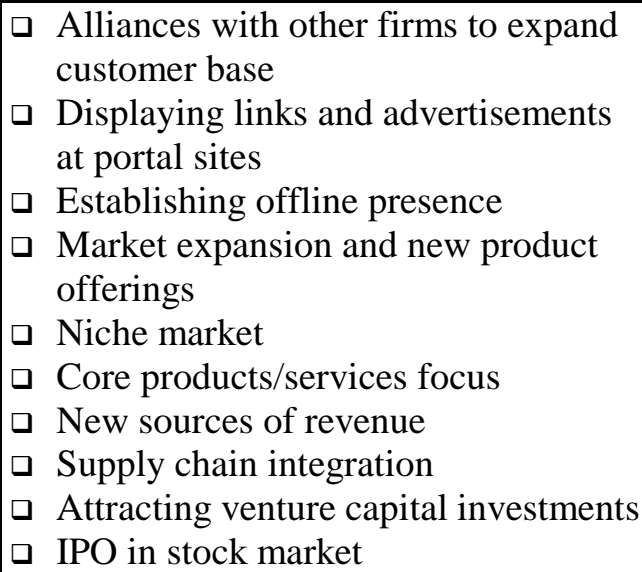 \\
\hline
\end{tabular}

Table 1. Strategies for DotCom Morphing 
The reader should recognize that firms do not have control over all of the drivers of their ability to survive. For example, once founded, senior managers hardly have control over exogenously determined industryspecific factors, such as rate of new firm entry, industry growth, and the overall technological regime of the industry. These factors condition the external environment in which DotComs operate. Among the firmspecific factors, founding time remains fixed once a firm is established, and is irrelevant in the morphing process, even though it may play a role in determining the firm's baseline likelihood of survival.

\section{Firm-Specific Drivers of Success}

We next discuss the "genes" and related strategies for DotCom survival that emphasize the firm-specific aspects.

Survival Factors. Previous research indicates firm size and the percentage of insider ownership are positively related to firm survival. On the other hand, independent new startups are more likely to fail than new divisions of an existing firm.

Related Strategies. DotComs can enlarge their size by expanding into other markets, and through mergers and acquisitions. However, firms also need to be cautious in their efforts to rapidly expand. The entrance of Priceline.com into the gasoline market and its subsequent retreat is just one of many instances of DotCom firms that sought market expansion but ended up with less than favorable outcomes.

To avoid the disadvantage of being independent startups, DotComs can form strategic alliances with existing companies. The knowledge, infrastructure and financial backup that DotComs receive from these alliances can help them operate at lower costs and grow faster, especially during the initial stages.

\section{EC-Related Drivers of Success}

Electronic commerce-related survival factors are also a crucial part of the explanatory mix.

Survival Factors. The electronic commerce-related survival factors that we discussed earlier include achieving a critical mass and the adaptability of the business model to the digital marketplace. If a firm is the first to achieve a critical mass in its segment of the Digital Economy, it will present a higher entry barrier to other newcomers and will have the lead time that is needed to expand into other markets with its existing customer base.

A sound business model is also a crucial gene for DotCom success. Here we emphasize the value, revenue, logistical and capital formation aspects. To survive in the long-run, DotComs first must deliver unique value to their customers and suppliers. In addition, they also need to maintain steady sources of revenue to sustain themselves, to carefully design the logistics stream to fully integrate the supply chain and operate at low costs, and to consider what will be necessary to place their firms in an advantageous position relative to the capital market - in good and bad economic times.

Related Strategies. We next discuss the issues of critical mass and business model in greater depth. 
Critical Mass. To reach the requisite critical mass, DotComs often form strategic alliances so that they have access to each other's customer bases. Other strategies to achieve critical mass include displaying links and advertisements at portal sites, using different media to market their brand names, and partnering with firms in the physical world to maintain an offline presence.

Business Model. DotComs have different options that they can explore in the adjustment of their business model, depending on the competitive position they hold in the marketplace. Market leaders can expand their product and service offerings and penetrate new markets, a business segment that GartnerG2 characterizes as high in innovation and low in adaptation (Rountreem 2001a). Market followers, since they are less wellpositioned to pursue aggressive business strategies, need to identify niche markets and avoid head-on competition with market leaders, using the strategies of low innovation but high adaptation. Those that cannot innovate or adapt, market losers, fall out. Market masters have the resources to innovate and the flexibility to adapt, and maintain success in the market over time.

Business models that are founded on securing market share in lieu of a focus on profitability are proven not to be viable. Moreover, for DotComs that expanded too fast and are now saddled with unattractive fixed costs of operation, the focus has shifted to a greater emphasis on core product and service offerings and targeting the most profitable customers. DotComs also can explore alternative sources of revenue as the existing ones are no longer sufficient. For example, many online content sites, which primarily depended on advertising in the past, now charge fees for the information they provide to remain viable. In terms of logistics, firms are integrating with their suppliers and customers to reduce costs and boost profits. Firms that can attract a large amount of venture capital are better positioned for survival and future growth. The additional influx of money when firms go public in the stock market will also help them obtain additional financial capital.

In the above discussion, we identify the strategies Internet firms can take to try to be competitive. However, the strategies are not independent of each other. For example, the amount of venture capital a DotCom can attract relates closely to the qualities of its business model. This is because investors will only fund those companies that they think are promising and can deliver value and attractive profits.

In the next section, we illustrate how real world companies implement the above-mentioned strategies to enhance their likelihood of success.

\section{DOTCOM MORPHING MINI-CASES}

To provide a representative sample of the DotComs to examine the efficacy of the interpretations that we propose, we include in our mini-case studies both B2C firms offering products and services and B2B sites.

\section{Mercata.com}

Bellevue, Washington-based Mercata.com was a group-buying firm which allowed consumers to aggregate their purchasing power and obtain volume discounts that they would otherwise be unable to obtain 
individually. Founded in September 1998, Mercata was backed by Paul Allen's Vulcan Ventures and launched its Web site in May 1999, carrying over 1,000 consumer goods from 150 manufacturers (Reuters, 1999). Mercata's value proposition to its customers was the lower price they could get by aggregating customer orders. By obtaining its supplies directly from manufacturers, Mercata tried to reduce its costs maintain a thinner margin above the manufacturer's price (Browder, 1999).

Mercata's initial strategy was to market its brand name and expand its product offerings and customer base, which it spent millions of dollars to acquire (Kauffman and Wang, 2002). For example, its advertising campaign "Down is Good" won two "Telly Awards" (Business Wire, 2000a). Mercata also promoted its site on MSN eShop, MSNBC, WindowsMedia.com, Entertainment channels, and on the Slate online magazine ( $P R$ Newswire, 2000a), as well as featuring its full-page ads in the Wall Street Journal and New York Times. To acquire new customers, Mercata gave $\$ 100$ in sign up bonuses to consumers, who could later use the money toward 50\% off their purchases. Donating \$186,000 to Oprah Winfrey's charity Angel Network, Von Horn, CEO of Mercata, appeared on Oprah and promoted his company to the show's six million viewers (McHugh, 1999).

In terms of its product line expansion, Mercata encouraged customers to suggest the products it should carry. In the second half of 1999, based on customer suggestions, Mercata expanded its product line to include categories such as baby items, appliances, luggage, watches and jewelry (Business Wire, 1999b). Using the "We-Commerce" network, Mercata also provided group-buying technology solutions to other sites and merchants who wanted to sell products and services this way. They launched their "We-Commerce Affiliates" program in September 1999 (Business Wire, 1999a). In May 2000, Mercata teamed up with AT\&T and OmniSky to provide its customers wireless access to its group-buying markets (Business Wire, 2000b; Cambridge Telecom Report, 2000).

In the beginning, Mercata's strategies seemed to be paying off. There were more than 10,000 orders for some of Mercata's largest buying groups (Mara, 2000) and the company filed for an IPO of \$100 million in March 2000 (Von Horn, 2000). In addition, Mercata received its first Internet group-buying patent in August 2000 (Business Wire, 2000c).

In Fall 2000, Mercata engaged in even more ambitious growth plans. Its new services included a dynamic rebate program where the value of a rebate or coupon increased as the number of people using it increased (Business Wire, 2000d). It also provided group-buying solutions to all MSN eShop merchants (Business Wire, 2000g), a group-buying rebate promotion on the Buick Century automobile (Business Wire, 2000f), and the opening of Mercata Marketplace where third-party sellers could offload their products or services using the demand aggregation format (Business Wire, 2000e).

Later, however, following a withdrawal of its IPO on January 3, Mercata closed its doors abruptly at the 
end of the month because of the shortage of additional funding (Sandoval and Kawamoto, 2001). All told, Mercata ran though some $\$ 90$ million of capital made available to it by Vulcan Ventures and other investment firms.

Backed by Paul Allen's Vulcan Ventures, Mercata started with an advantage in the financial capital aspect of its business model. This allowed the firm to expand quickly into other markets and launch expensive marketing campaigns. By taking supplies directly from manufacturers, Mercata also enjoyed lower costs, reflecting a solid logistical aspect of its business model. In addition, by using the "We-Commerce" network, Mercata penetrated into the B2B marketplace and enabled other businesses to sell in bulk using its demand aggregation technology. These facts seemed to indicate that the company was a healthy startup with genes we identified earlier as critical to DotCom survival. Mercata was expected to increase scale size, expand into new markets and achieve a critical mass.

However, why did Mercata fail after only two years of operation? Even though its failure was a direct consequence of the management team's assumption of continuous funding, closer examination reveals a flawed business model with structural aspects that caused it to fail to achieve critical mass (Kauffman and Wang, 2002). The limited volume accumulated at the site prevented Mercata from realizing its low price value proposition, which ultimately drove consumers elsewhere. As we pointed out earlier, the value stream is crucial to the long-term sustainability of a business model. Without delivering value to its customers, Mercata was eventually selected out of the game by the competition in the marketplace.

\section{Peapod.com}

Peapod Inc.'s (www.peapod.com) search for a viable business model is a good example of a DotCom that has experimented and has been trying to find out what works. Peapod initially provided grocery delivery service to about 400 households in Evanston, Illinois. Customers placed orders online, though not over the Internet (Peapod.com, 2001). By 1998, the firm began to accept orders through the Internet, and its services grew to cover eight local metropolitan areas with about 100,000 households overall by 1999 (Peapod.com, 1999c).

Because of the limited market it served initially, Peapod partnered with grocers in local markets to fulfill orders (Keh and Shieh, 2001). With the anticipated demand increase for its service, Peapod opened its dedicated distribution centers in 1998 and shifted toward a warehouse-based fulfillment model to reduce costs and enhance margins (Peapod.com, 1998), which changed the logistical aspect of its business model. In 1999, Peapod launched its national service "Peapod Packages," which allowed consumers in the 48 contiguous states to place online orders for non-perishable groceries and other household products (PR Newswire, 1999b).

To market its service and attract new customers, Peapod undertook a series of strategies, including promoting its site at portal sites (PR Newswire, 1998), introducing an affiliates program (Peapod.com, 1999c), 
and pursuing cross-promotion with other food related Web sites (Peapod.com, 1999e). To expand its product offerings, Peapod also collaborated with Walgreens, a national drug retail chain, to provide health and beauty products to its San Francisco market (Peapod.com, 1999a). The firm also added new features to its Web site to enhance the customer experience (Peapod.com, 1999d). Peapod initiated an online research cooperative where, by paying a fee, subscribers could participate in various cooperate and customized market testing research to evaluate the impact of different marketing techniques in the online grocery market (Peapod.com, 1999b).

Peapod's initial strategies were to grow its business by entering new local markets, expanding its product offerings, and promoting its sites. With these strategies, Peapod tried to enlarge scale and sign on a critical mass of customers. The addition of national delivery of non-perishable foods also enabled Peapod to provide convenient service to its customers, an enhancement in its core value proposition. In evolutionary game theory terms, these strategies reflect Peapod's initial focus on three genes crucial to DotCom survival: firm size, reaching a critical mass and a value stream that warrants long-term sustainability.

In April 2000, Peapod formed a strategic alliance with Royal Ahold, an international grocery retailer, wherein the latter obtained a majority share of the former's stock (Peapod.com, 2000a). This partnership changed the logistical aspect of Peapod's business model and allowed Royal Ahold to leverage its retail food operations for the online grocery delivery service Peapod provided. Subsequently, Peapod acquired Streamline.com and resumed the latter's delivery service in Chicago and Washington, D.C. (Peapod.com, 2000c). With the infrastructure available at the Ahold-branded grocers, Peapod penetrated into two new markets, southern Connecticut and Washington D.C. (Peapod.com, 2000b, 2000d).

Later business adjustments would reflect increasing concerns about profitability and survival. Peapod scaled back its operations over, exiting markets in Ohio and Texas (Peapod.com, 2000c). In April 2001, Peapod ceased serving San Francisco, and ended its "Peapod Packages" service in May (Bloomberg News, 2001). In July 2001, Ahold announced plans to rescue the financially-troubled Peapod, purchase the remaining shares, and make it a subsidiary (Business Wire, 2001b).

This changed three aspects of Peapod's capabilities that relate to its survival. First, it is no longer an independent startup but a division of an existing international retail chain. Peapod benefits from Royal Ahold's knowledge from its operation in the physical grocery market. Second, with Royal Ahold's financial backing, Peapod also enjoys a steady influx of financial capital. Finally, with the support from Ahold-branded grocers, Peapod has lower operational costs and a more viable logistical implementation of its business model.

Peapod's journey illustrates how a DotCom changes its genes and strategies based on market feedback. Based on optimistic estimates about demand, Peapod penetrated eight local markets and built several distribution centers. Its subsequent retreat from the Ohio, Texas and San Francisco markets indicate that 
expanding without a sound plan or cost control mechanisms in place inevitably will lead to further problems down the road. Without Royal Ahold's financial backing, Peapod would have followed ended up like rival, WebVan. Access to enough financial capital clearly can make difference.

A lesson that Peapod learned the hard way is gauging whether current market demand warrants the existence of pure-play online grocers. The operational costs of a dedicated warehouse require a large number of orders just to break even, a scale size and organizational design consideration. With the online grocery industry still in its early stages, partnering with existing bricks-and-mortar grocers might have been a better choice.

\section{PayPal.com}

Palo Alto, California-based PayPal.com (www.paypal.com) was founded in December 1998 and launched its Web site in October 1999. PayPal provides person-to-person (P2P) online payment service though PCs, PDAs and mobile phones. In March 2000, PayPal merged with another P2P payment service provider X.com and operates under the name X.com's PayPal (Newsbytes, 2000a).

After signing up for an account, an individual or business can send money to anyone else that has an email account, without knowing the latter's bank account number. Sending and receiving money through PayPal was initially free. But starting in Fall 2000, PayPal began to charge its business users a flat fee plus a percentage of the total transacted amount (Sandoval, 2000). Now, Individuals can get up to $\$ 100$ in personal payment each month for free. Sending money is free of charge. PayPal also makes money by obtaining interest on idle amounts sitting in its users' accounts. PayPal's value proposition is its fast and convenient payment solutions, especially for auction participants. By partnering with MasterCard and Providian Financial Corporation, PayPal offers co-branded debit cards and credit cards to its customers, who can spend the money in their accounts both online and offline (Newsbytes, 2000b; Business Wire, 2001a).

During a two-year period, PayPal has secured about $\$ 225$ million in total equity financing, with impressive rounds of funding of $\$ 100$ million in April 2000 and $\$ 90$ million in March 2001 (Newsbytes, 2001). This is viewed as a "killer app" for the Internet by many observers (PR Newswire, 1999c), and the interest level among investors reveals a sense of the market's expectations about the efficacy of PayPal's business model.

Paralleling the success of online auctions, PayPal has enjoyed a steady increase in its customer base: it currently has a total of more than 9 million users in 36 countries. To further expand its customer base, PayPal also partners with sites such as Evite.com ( $\underline{\text { www.evite.com) }}$ ) to promote its $\mathrm{P} 2 \mathrm{P}$ payment services $(P R$ Newswire, 2000c). However, PayPal faces challenges from other P2P payment solution providers. Eyeing PayPal's success and the fact that two-thirds of eBay users already use PayPal's service, eBay launched its own P2P payment service, BillPoint, to obtain greater leverage on the aftermarket portion of its value chain. Traditional banks are also trying to catch up. Citibank initiated a similar P2P payment service called "c2it" 
(www.c2it.com) and partnered with AOL to market the service available to the latter's 28 million users (Trombly, 2000). As a result, PayPal faces tough competition despite its current lead in the market.

A gene that is fundamental to PayPal's initial success is the value stream of its business model. The largescale online auctions among consumers and small businesses that cannot accept credit cards require a secure and convenient method of payment. PayPal fills in this "blank on the map" by providing instant and convenient payment solutions. In addition, PayPal also has a snowballing effect built into its gene related to achieving a critical mass. The firm enjoys relatively low customer acquisition costs since some people sign up and start using PayPal simply because they received a payment in their email accounts. Presumably the firm has done the math to determine that the value of a sign-up exceeds this subsidy cost. These two fundamental genes, along with the firm's growth and market expansion efforts through mergers and strategic alliances, allow PayPal to stand out among its competitors. A sound business model with promising market performance further enables PayPal to attract investments from the venture capital market, allowing it to try out other new growth strategies.

\section{GetThere.com}

The travel industry has gone through significant transformation in recent years, with the disintermediation of traditional travel agencies, and then later their reintermediation in the digital marketplace (Chircu and Kauffman, 2000). By providing more choices at lower prices, newly-emerged online travel agencies captured a significant portion of the market share and displaced traditional travel agencies. The latter, taking various strategies to Web-enable their services, managed to fight back and recapture some of their lost market. Recently however, in the context of extreme pressures overall in the travel reservations industry, online travel sites have gone though a major shakeout, with numerous mergers and acquisition occurring. It is during this period that GetThere has emerged as one of the largest corporate travel service providers on the Internet.

GetThere.com (www.getthere.com), under its former name of Internet Travel Network (ITN), started to provide online booking services for corporate travelers as early as 1995. Although it began with airline reservation only, the company added car and hotel reservations in 1996, restaurant and group transportation reservations in 2000, and meeting planning in 2001. In addition to expanding its travel related services, GetThere collaborates with other application service providers, such as Portable Software (GetThere.com, 1997b) and Ariba Software (PR Newswire, 1999a), to better integrate its reservation systems with external corporate planning and control systems. Today, GetThere provides a spectrum of booking solutions that enable travel agencies and corporations to customize and integrate it with their own systems. In addition, GetThere also supports the online reservation systems at airlines such as United, TWA, and British Airways.

GetThere is another example of a DotCom with a sound business model that equates with favorable genetic traits for competition. It confers significant value on its customers. Using its service, for example, corporate 
travelers can obtain more information about their travel options, and schedule a complete trip with air, hotel and car reservations bundled up in one transaction. More importantly, the firm delivers low cost services to its customers and allows companies to reduce their managed travel budgets. The partnership with other application service providers also allows GetThere to provide to its customers a system that they can easily integrate with their existing corporate applications.

As ITN, the company received two rounds of venture capital funding of \$4.2 million in May 1996 and \$6.5 million in July 1997, respectively (GetThere.com, 1996 and 1997a). In July 1999,when the company changed its name to GetThere.com, it was setting up to go public. Its IPO that year changed the financial capital aspect of GetThere's business model and giving it additional financial resources with which to grow.

In June 2000, GetThere acquired Automated Travel Systems, Inc. for $\$ 13.5$ million. The latter's technology allows GetThere to connects buyers directly with travel suppliers and perform live searches over the Internet (PR Newswire, 2000b). In Fall 2000, Sabre, a former competitor, acquired GetThere for $\$ 757$ million, forming the single largest online B2B travel marketplace (George, 2000). Today GetThere is able to benefit from Sabre's experience and succeed in the online travel industry.

\section{DISCUSSION AND CONCLUSIONS}

In this paper, we propose an evolutionary game theory-motivated framework for DotCom strategic morphing. We argue that, to survive in the electronic marketplace, Internet firms change their strategy "genes" to remain competitive in the game. Through trial and error, they come to realize what works and what does not, and adjust their organizational tactics and strategies accordingly. Those that adopt superior strategies survive. Those that adopt inferior strategies will be weeded out by the competition in the marketplace.

Based on previous research on business success and failure, we also identified a set of "genes" that are crucial to DotCom survival and over which Internet firms have control. We proposed firm-specific factors such as firm size, insider ownership, and whether the firm is an independent new startup or a new branch of an existing business. We also proposed e-commerce-specific factors such as the extent of critical mass and the soundness of the business model. We conceptualized this in terms of four streams that characterize a business model: the value, revenue, logistical and financial capital steams.

Using mini-cases to illustrate success and failure of Internet-based firms, we illustrate how our framework can shed light on the DotCom morphing process. Some common strategies taken by the four firms we studied include market expansion efforts by introducing new products, acquiring new customers and forming strategic alliances. These strategies allow firms to favorably change several of their genes for the game, such as business size and achieving a critical mass. Even though these strategies are instrumental to DotCom survival, both successful and failed firms used these strategies indicating that they are not sufficient for a viable business. 
To remain competitive, a company has to have a business model with a strong core value proposition. The success stories of PayPal and GetThere demonstrate the dimensions of value that an intermediary has to provide value to its customers: in particular, the value stream aspect we have emphasized. On the other hand, Mercata's failure to appropriate value from the marketplace for its "low price" value proposition eventually drove customers and investors away, leading to its outright failure. Peapod, meanwhile, illustrates a DotCom in search of a sustainable business model, especially in terms of its logistical and financial capital streams. With online grocery market still in its infancy, Peapod was ahead of its time and found out that building dedicated warehouses was not cost-effective. Its rescue by Royal Ahold also demonstrates the importance of having a strong financial capital stream.

As the first step toward understanding what drives DotCom survival, the current research develops a framework that tackles the DotCom morphing process through the lens of evolutionary game theory. Our insights can help the academic community to better understand the successes and failures we observe in the digital marketplace. In addition, the firm-specific and e-commerce-specific factors and the strategies that we propose in this paper gives managers of Internet firms a checklist against which they can examine their current business and identify directions for change.

\section{REFERENCES}

[1] Audretsch, D.B. New Firm Survival and the Technological Regime. The Review of Economics and Statistics, 60, 3 (August 1991), 441-450.

[2] Audretsch, D.B. Innovation and Industry Evolution. Cambridge, MA: MIT Press, 1995.

[3] Audretsch, D.B., and Mahmood, T. The Hazard Rate of New Establishments: A First Report. Economic Letters, 36, 2 (May 1991), 409-412.

[4] Audretsch, D.B., and Mahmood, T. New Firm Survival: New Results Using a Hazard Function. The Review of Economics and Statistics, 77, 1 (February 1995), 97-103.

[5] Ba, S.; Whinston, A.B.; and Zhang, H. The Dynamics of the Electronic Market: An Evolutionary Game Approach. Information Systems Frontiers, 2, 1 (January 2000), 31-40.

[6] Bakos, Y. The Emerging Landscape for Retail E-Commerce. Journal of Economic Perspectives, 15, 1 (Winter 2001), 69-80.

[7] Bloomberg News, Peapod Scales Back Service to Focus on Five Markets, May 18, 2001. Available on the Internet at investor.cnet.com/investor/news/newsitem/0-9900-1028-5863919-0.html.

[8] Browder, S., Paul Allen's e-commerce play: Bring the buying club to the net, BusinessWeek, May 13, 1999. Available on the Internet at www.businessweek.com/ bwdaily/dnflash/may1999/ nf90513c.htm

[9] Burnham, B. How to Invest in E-Commerce Stocks, McGraw-Hill, New York, NY, 1999.

[10] Business Wire, Mercata Launches We-Commerce Affiliate Program; Affiliates Add Unique Shopping Experience to their Web Sites by Offering Access to Mercata.com, September 14, 1999a. Available on the Internet at www.findarticles.com/cf_0/m0EIN/ 1999_Sept_14/55738537/p1/article.jhtml. 
[11] Business Wire, Mercata Listens to Its Customers and Delivers; Customer-Drive Company Adds Six New Departments in Less than Six Months, October 27, 1999b. Available on the Internet at www.findarticles.com/cf_0/m0EIN/1999_Oct_27/56945138/p1/article.jhtml.

[12] Business Wire, Mercara's Television Commercials Honored in $21^{\text {st }}$ Annual Telly Awards; Group Buying E-Commerce Company Takes Home Silver and Bronze Awards for Outstanding Creative Achievements, April 11, 2000a. Available on the Internet at www.findarticles.com/ m0EIN/ 2000_April_11/61423048/p1/ article.jhtml.

[13] Business Wire, Group Buying Goes Wireless Through Mercata and OmniSky Alliance; We-Commerce Network to Power Wireless Application and Provide Access to Mercata from Palm Pilots, May 3, 2000b. Available on the Internet at www.findarticles.com/ cf_0/m0EIN/2000_May_3/61872045/ p1/article.jhtml.

[14] Business Wire, Mercata Receives the First Internet Group Buying Patent; First Patent in Group Buying Space Issued to Mercata for Business Methods and Technology, August 9, 2000c. Available on the Internet at www.findarticles. com/cf_0/m0EIN/ 2000_August_9/63962501/p1/article.jhtml.

[15] Business Wire, Mercata Offers Group Buying Solution to Allow Manufacturers and Retailers to Launch 'Dynamic Rebates;' Viral Rebate Program Supercharges Rebate and Coupon Promotions, October 25, 2000d. Available on the Internet at www.findarticles. com/cf_0/m0EIN/2000_Oct 25/66319065/p1/article.jhtml.

[16] Business Wire, Mercata Launches Compelling Alternative to Online Auctions; More Than 900 ThirdParty Sellers Pre-Register for Mercata's New Platform for Self-Service Demand Aggregation,

November 15, 2000e. Available on the Internet at www.findarticles.com/cf 0/m0EIN/ 2000 Nov 15/ 66953819/ p1/article.jhtml.

[17] Business Wire, Mercata “Drives" New Buyers to Buick; First Nationwide Auto Group Purchase Reaches New Audiences, November 21, 2000f. Available on the Internet at www. findarticles.com/cf_0/m0EIN/2000_Nov_21/67175005/p1/article.jhtml.

[18] Business Wire, Mercata Selected as Provider of Group Buying Technology for MSN eShop Internet's Fastest Growing Shopping Destination Offers Group Buying Technology to All MSN eShop Merchants, December 18, 2000g. Available on the Internet at www.findarticles.com/ cf 0/m0EIN/2000 Dec 18/68142627/ p1/article.jhtml.

[19] Business Wire, Providian and PayPal Forge Strategic Alliance; Partnership Brings Together America's Fifth Largest Bankcard Company with the Number One Online Payment Provider, February 6, 2001 a. Available on the Internet at www.findarticles. com/cf_0/m0EIN/2001

Feb_6/70026162/p1/article.jhtml.

[20] Business Wire, Ahold to Acquire All Outstanding Shares in Peapod, America's Leading Internet Grocer, July 16, 2001b. Available on the Internet at investor.cnet.com/ investor/news/ newsitem/09900-1028-6577362-0.html.

[21] Cambridge Telecom Report, AT\&T Wireless and Mercata Launch Group Buying Through Wireless Web Phones; We-Commerce Network to Power AT\&T Digital PocketNet Service, May 22, 2000. Available on the Internet at www.findarticles.com/cf_0/ m0BFP/ 2000_May_22/62216420/p1/article.jhtml

[22] Chircu, A.M., and Kauffman, R.J. Reintermediation in Business-to-Business E-Commerce. International Journal of Electronic Commerce, 4, 4 (Summer 2000), 7-42. 
[23] Cook, J. Venture Capital: Where Mercata Led, Consumers Were Unwilling to Follow. Seattle PostIntelligencer (January 12, 2001). Available on the Internet at seattlep-i.nwsource.com/ business/ vc122.shtml.

[24] Downes, L., and C. Mui. Unleashing the Killer App: Digital Strategies for Market Dominance, Harvard Business School Press, Cambridge, MA, 1998.

[25] Dybvig, P. H., and Spatt, C. Adoption Externalities As Public Goods. Journal of Public Economics, 20, 2 (March 1983), 231-247.

[26] Economides, N. The Economics of Networks. International Journal of Industrial Organization, 14, 2 (October 1996), 673-699.

[27] George, T. Sabre Buys GetThere to Grow Travel Lead. InformationWeek, 802 (September 4, 2000), 117.

[28] GetThere.com. Venture Partners Invest \$4.2 Million in Internet Travel Network, May 20, 1996. Available on the Internet at www.getthere.com/news_events/news/ pr025.html.

[29] GetThere.com. Norwest Venture Capital Invests \$1.25 Million in Internet Travel Network, July 8, 1997a. Available on the Internet at www.getthere.com/ news_events/news/ pr051.html.

[30] GetThere.com. Internet Travel Network, Portable Software Enter Alliance, July 28, 1997b. Available on the Internet at www.getthere.com/news_events/news/pr056.html.

[31] Hensler, D.A., Rutherford, R.C., and Springer, T.M. The Survival of Initial Public Offerings in the Aftermarket. The Journal of Financial Research, 20, 1 (Spring 1997), 93-110.

[32] Honjo, Y. Business Failure of New Firms: An Empirical Analysis Using a Multiplicative Hazards Model. International Journal of Industrial Organization, 18, 4 (May, 2000), 557-574.

[33] Katz, M.L., and Shapiro, C. Technology Adoption in the Presence of Network Externalities. Journal of Political Economy, 94, 4 (August 1986), 822-841.

[34] Katz, M.L., and Shapiro, C. Systems Competition and Network Effects. Journal of Economic Perspectives, 8, 2 (Spring 1994), 93-115.

[35] Kauffman, R.J., and Wang, B. New Buyers' Arrival Under Dynamic Pricing Market Microstructure: The Case of Group-Buying Discounts of the Internet, Journal of Management Information Systems, 18, 2 (Fall 2001), forthcoming.

[36] Kauffman, R.J., and Wang, B. Bid Together, Buy Together: On the Efficacy of Group-Buying Business Models in Internet-Based Selling. Forthcoming in P.B. Lowry, J.O. Cherrington, and R.R. Watson (editors), Handbook of Electronic Commerce in Business and Society, Boca Raton, FL: CRC Press, 2002.

[37] Keh, H.T., and Shieh, E. Online Grocery Retailing: Success Factors and Potential Pitfalls. Business Horizons, 44, 4 (July-August, 2001), 73-83.

[38] Mahadevan, B. Business Models for Internet-Based E-Commerce: An Anatomy. California Management Review, 42, 4 (Summer 2000), 55-69.

[39] Mara, J. Good Buys. Adweek, 41, 10 (March 6, 2000), 58-64.

[40] McHugh, J. Consumer Collusion! Forbes, 164, 5 (September 6, 1999), 222-223.

[41] Miller, T. Startup.com: How 125 Internet Companies Are Remaking Themselves in Search of Post Shakeout Success. Webmergers.com, San Francisco, CA, June 2001. 
[42] Mougayar, W. Opening Digital Markets: Battle Plans and Business Strategies for Internet Companies, CommerceNet Press/McGraw-Hill, New York, NY, 1998.

[43] Newsbytes. X.com Gets Friendly With PayPal Over Online Payments, March 2, 2000a. Available on the Internet at www.findarticles.com/cf 0/m0NEW/2000_March 2/ 59733719/p1/article.jhtml.

[44] Newsbytes. PayPal Goes Offline With MasterCard Debit Card, December 22, 2000b. Available on the Internet at www.findarticles.com/cf_0/m0NEW/2000_Dec_22/68369439/p1/article.jhtml.

[45] Newsbytes. PayPal Closes $\$ 90$ Million In Financing, March 7, 2001. Available on the Internet at www.findarticles.com/cf_0/m0NEW/2001_March_7/71352108/p1/article.jhtml.

[46] Oliver, R.W. The Seven Laws of E-Commerce Strategy. Journal of Business Strategy, 21, 5 (September/October 2000), 8-10.

[47] Peapod.com. Peapod Opens First Dedicated Distribution Center --Internet Grocery Service Commences in Long Island, December 3, 1998. Available on the Internet at www.peapod.com/fcgibin/fetch.fcg?msgid=5112.

[48] Peapod.com. Peapod and Walgreen Co. Announce Product Alliance; Companies to Partner in Peapod's New Service Model in San Francisco, March 10, 1999a. Available on the Internet at www.peapod.com/fcgi-bin/fetch.fcg? msgid=5109.

[49] Peapod.com. Peapod Launches Innovative Online Research Service -- Names First Blue Chip Subscribers, March 18, 1999b. Available on the Internet at www.peapod.com/ fcgibin/fetch.fcg?msgid=5108.

[50] Peapod.com. Peapod Announces Affiliates Program: Unique Arrangement Yields Quicker Revenues for Partners, April 27, 1999c. Available on the Internet at www.peapod.com/fcgibin/fetch.fcg?msgid=5105.

[51] Peapod.com. Peapod Announces New Site Features to Help Consumers Shop Smarter and Faster, September 22, 1999d. Available on the Internet at www.peapod.com/fcgi-bin/fetch.fcg?msgid=5129.

[52] Peapod.com. Peapod and Food.Com Announce Strategic Marketing Agreement -- Will Cross-Promote Services and Benefits, September 30, 1999e. Available on the Internet at www.peapod.com/fcgibin/fetch.fcg?msgid=5137.

[53] Peapod.com. Ahold Forms Partnership with US Internet Grocer Peapod, April 14, 2000a. Available on the Internet at www.peapod.com/fcgi-bin/fetch.fcg?msgid=5718.

[54] Peapod.com. Peapod by Stop \& Shop Offers Online Grocery Shopping and Delivery Service in Connecticut -- Model Illustrates Benefits Achieved with Peapod/Royal Ahold Partnership, June 20, 2000b. Available on the Internet at www.peapod.com/fcgi-bin/ fetch.fcg? msgid= 5829.

[55] Peapod.com. Peapod Acquires Streamline.Com, Inc.'s Operations in Two Key Markets -- Exits Texas and Ohio; Announces Plans to Enter Baltimore-Washington, September 7, 2000c. Available on the Internet at www.peapod.com/fcgi-bin/fetch.fcg?msgid=6023.

[56] Peapod.com. Peapod By Giant Launches Online Grocery Shopping and Delivery Service in Nation's Capital, November 2, 2000d. Available on the Internet at www.peapod.com/fcgi-bin/fetch.fcg? $\underline{\text { msgid }=6180}$.

[57] Peapod.com. Corporate Fact Sheet, July 2001. Available on the Internet at www.peapod.com/ppod/Updated factsheet July 2001.pdf. 
[58] PR Newswire. Peapod Signs Multi-Year Internet Marketing Deal with Excite, August 20, 1998. Available on the Internet at www.findarticles.com/cf_0/m4PRN/ 1998_August_20/21038876/ p1/article.jhtml.

[59] PR Newswire. Ariba Forges Alliance With GetThere.com for Business-to-Business Online Travel, October 12, 1999a. Available on the Internet at www.findarticles.com/cf 0/ m4PRN/ 1999 Oct 12/56210598/p1/article.jhtml.

[60] PR Newswire. America's Largest Internet Grocer, Launches National Service, October 18, $1999 \mathrm{~b}$. Available on the Internet at www.findarticles.com/cf_0/m4PRN/1999_Oct_18/56451688/p1/article.jhtml.

[61] PR Newswire. Beaming Money By Email Is Web's Next Killer Ap, November 16, 1999c. Available on the Internet at www. findarticles.com/cf 0/m4PRN/1999 Nov 16/57589612/p1/article. jhtml.

[62] PR Newswire. Mercata Launches Spring Promotional Sponsorship on MSN, April 3, 2000a. Available on the Internet at www. findarticles.com/cf 0/m4PRN/2000 April 3/61710153/p1/article.jhtml.

[63] PR Newswire. GetThere Acquires Automated Travel Systems, Inc., June 22, 2000b. Available on the Internet at www.findarticles.com/ cf_0/m4PRN/2000_June_22/62874975/p1/article.jhtml.

[64] PR Newswire. Evite, Inc., Partners With X.com's PayPal to Bring Online Person-to-Person Payments to Millions of Users, June 27, 2000c. Available on the Internet at www.findarticles.com/cf_0/ m4PRN/2000 June 27/62984546/p1/article.jhtml.

[65] Reuters. Allen's New E-Commerce Model, ZDNet.com (May 16, 1999). Available on the Internet at www.zdnet.com/ zdnn/stories/0,45862259826,00.html.

[66] Rountree, D. Building Business on Quick Lending Decisions, Bank Technology News, 14, 8 (August 2001a), 1-5. Available on the Internet at www.banktechnews.com/ btn/articles/btnaug01-2.shtml.

[67] Rountree, D. Surveying the Online Banking Channel. Bank Technology News, 14, 8 (August 2001b), 1-4. Available on the Internet at www.banktechnews.com/btn/ articles/btnaug01-1.shtml.

[68] Samuelson, L. Evolutionary Games and Equilibrium Selection, Cambridge, MA: MIT Press, 1998.

[69] Sandoval, G. PayPal Cracks Down on Business Customers. CNet News.com, October 4, 2000. Available on the Internet at news.cnet.com/news/0-1007-200-2932909.html.

[70] Sandoval, G., and Kawamoto, D. Group-Buying Site Mercata to Shut Its Doors. CNet News.com (January 4, 2001). Available on the Internet at news.cnet.com/news/0-1007-200-4372403.html.

[71] Smith, J.M. Evolution and the Theory of Games, Cambridge, UK: Cambridge University Press, 1982.

[72] Trombly, M. Citigroup Launches Electronic-Cash Service. Computerworld, 34, 45 (November 6, 2000), 8 .

[73] Venture Economics. 2000 Year-in-Review. Available at www. ventureeconomics.com/ news_ve/ 2001VEpress/ 2000 Year In Review.pdf, 2000.

[74] Van Horn, T. Mercata Files for $\$ 100$ million IPO. CNet News.com (March 9, 2000). Available on the Internet at news.cnet.com/news/0-1007-200-1568987.html.

[75] Webmergers.com. July Report: Shutdowns Fall Sharply; M\&A on Par with April and May (Summary). Available at www. webmergers.com/ editorial/article.php?id=39, August 2001.

[76] Weibull, J.W. Evolutionary Game Theory, Cambridge, MA: MIT Press, 1997.

[77] Westland, J.C., and Clark, T.H.K. Global Electronic Commerce: Theories and Case Studies. Cambridge, MA: MIT Press, 1999. 